\title{
An Empirical Survey on Factors Affecting Citizens' Trust in Public Institutions in the Eastern Province of Sri Lanka
}

\author{
A. Rameez ${ }^{1} \&$ M. A. M. Fowsar ${ }^{2}$ \\ ${ }^{1}$ Senior Lecturer in Sociology, South Eastern University of Sri Lanka, Sri Lanka \\ ${ }^{2}$ Lecturer in Political Science, South Eastern University of Sri Lanka, Sri Lanka \\ Correspondence: A. Rameez, Senior Lecturer in Sociology, South Eastern University of Sri Lanka, Sri Lanka. \\ E-mail: arameez@seu.ac.lk
}

$\begin{array}{lrr}\text { Received: April 2, } 2018 & \text { Accepted: April 25, } 2018 & \text { Online Published: May 31, } 2018 \\ \text { doi:10.5539/jpl.v11n2p88 } & \text { URL: https://doi.org/10.5539/jpl.v11n2p88 }\end{array}$

This study was funded by Asia Foundation, Sri Lanka.

\begin{abstract}
Although Sri Lanka made attempts to adopt policies of decentralization and democratic governance to enhance citizens' trust, the efforts had yielded very little success. As such, this study attempts to assess the level of citizens' trust in public institutions in the eastern province of Sri Lanka and explores the factors contributing to the decline of citizens' trust in public institutions. Both qualitative and quantitative methods consisting of questionnaire survey, in-depth-interview and focus group discussion as data collection techniques were employed in this study. Overall, it was found that the people have little trust in the public institutions due to lack of awareness, discrimination in terms of ethnicity, undue delay, lack of modern facilities and political influence. Thus, it is paramount on the part of government to address these challenges to restore the trust among the citizens on these public institutions.
\end{abstract}

Keywords: democracy, decentralization, discrimination, undue delay, political influence, lack of facilities

\section{Introduction}

Trust in public institutions refers to the degree to which individuals have higher level of confidence in public institutions of their country of residence. Trust is a significant element for explaining social events, such as function of democratic institutions, economic development and quality of government institutions. Moreover, trust is regularly conceptualized as a crucial dependent variable whereby good governance fosters increased citizens' trust in public institutions (Rothstein \& Teorell, 2012). Trust is important for the success of a wide range of public policies and institutions that depend on behavioral reactions from public, and thus, it is essential for enhancing the confidence of service providers and clients. Trust is also essential for economic and infrastructure development of a country. The success of government policies, decisions, schemes and programmes is also depending on the cooperation and compliance of citizens.

Literature defines the concept of citizens' trust from different angles. Given the complex nature of the concept, a clear understanding of it is important. Moreover, we consider the concept a significant indication for successful governance. Sztompka (1999) defines “citizens' trust in public institutions in terms of the extent people are confident in incumbents of public offices based on how they behave and act according to institutional norms, demands and aspirations as well as to what extent these are fulfilled." According to Marozzi (2014), "trust is a central element of social order and survival of any democratic regime." He further argues "that trust affects institutional performance, wellbeing, economic development and crime reduction. In his view, public institutions should pay close attention to citizens' trust in them particularly when introducing reforms aiming at improving their performance." Hence, we can simply define the concept of trust in public institutions as citizens' positive outlooks about members of public institutions and believe that they follow rules and regulations that will produce constructive outcomes for themselves and for society at large.

Trust shapes citizens' willingness to support in achieving collective goals and objectives of the society. It is crucial for social stability and economic growth in developing countries, like Sri Lanka. Citizens' trust in public institutions is important for a fruitful society. However, in Sri Lankan context, citizens' trust in the public 
institution is deteriorating owing to various reasons such as political uncertainty, corruption and poor governance. Dissatisfaction and lack of trust in public institutions have been observed in the eastern province although it has been liberated from Tamil rebels in 2007. Hence, to explore the level of trust and satisfaction in public institutions in the eastern province of the country is significant. The trauma that people undergo with public institutions, after almost three decades of violent civil war, has shaped the trust level of citizens in public institutions.

In the Sri Lankan context, several studies have been conducted on public governance systems in the country, but most of these works have been carried out within the traditional framework of governance. Many related studies have focused on democracy, rule of law and good governance in the Sri Lankan context and have particularly analyzed good governance practices and issues in the country (Somasundram, 1997). Furthermore, the studies of Warnapala (1974) are important, because, his study pays attention to the Ceylon Civil Service Administration. Thus, by and large, studies on the public sector governance in Sri Lanka have been mostly conducted in different angles by political scientists and others concerned with political institutions, formal regime shifts, nature of political parties and institutions and effectiveness of political parties (Silva, 1993; Ranatunga, 2002; Nanayakara, 1994; Mendis, 2008; Bastian, 2003).

Apart from those studies, Ramesh and Umadevi analyze (2017) the formative aspects of citizens' trust in public institutions in Sri Lanka. However, it attempts to bind the larger context into a small scope and its findings are more general. The above studies set the agenda for academic debates about citizens' trust in public institutions in Sri Lanka. Many of these studies have been designed with a macro framework in mind and do little to explain what public sector governance does for ordinary people. Here, the essential questions like how do people view themselves in the larger national context and how do they themselves analyze public institutions in their own cultural setting are something that this study attempts addresses. Thus, this survey attempts to assess the level of citizens' trust in public institutions in the eastern province of Sri Lanka and explores the factors for the decline of citizens' trust.

\section{Materials and Methods}

The empirical survey on citizens' trust in public institutions in the eastern province of Sri Lanka is based on both qualitative and quantitative research methods. The qualitative and quantitative data were gathered by using primary and secondary sources. The secondary data were collected through published books, research reports, journals and online archives. The primary data were collected in several field visits in each of the three districts. The research was commenced with a pilot visit to the respective research locations to gain an insight into the local socio-economic and political context.

The next source of information is the household survey and it was conducted in three districts to assess the level of citizens' trust in public institutions. 500 questionnaires were distributed among the public institutions in three districts. The questionnaire was translated into local language and a pilot survey was also conducted as mentioned above. Findings from the pilot survey and suggestions extended by consultants were taken into account in the finalization of the questionnaire.

The purposive and random sample selection strategy was used in order to ensure that the selected respondents represent the entire population and to avoid the biases. 15 in-depth interviews were carried out with local stakeholders to know the different perceptions on the level of citizen's trust in public institutions. The sample distribution is disaggregated in terms of gender (Table 1).

Table 1. Sample distribution (Gender)

\begin{tabular}{lcccccc}
\hline \multicolumn{1}{c}{ Districts } & Male & Samples & Female & Samples & Total & Total Samples \\
\hline Ampara & 314,810 & $\mathbf{9 4}$ & 333,247 & $\mathbf{9 9}$ & 648,057 & $\mathbf{1 9 3}$ \\
Batticalao & 285,447 & $\mathbf{8 5}$ & 301,154 & $\mathbf{9 0}$ & 586,601 & $\mathbf{1 7 5}$ \\
Trincomalee & 214,149 & $\mathbf{6 4}$ & 226,723 & $\mathbf{6 8}$ & 440,872 & $\mathbf{1 3 2}$ \\
Total & 814,406 & $\mathbf{2 4 3}$ & 861,124 & $\mathbf{2 5 7}$ & $1,675,530$ & $\mathbf{5 0 0}$ \\
\hline
\end{tabular}

A total of five research assistants participated in this survey and research assistants consisted of both male and female representing three districts. Prior to starting fieldwork, they were given comprehensive training on the study, the survey instrument and field techniques. The main researchers including consultants took responsibility 
to monitor field assistants to ensure the quality of the data collected. The preliminary results were also discussed in 6 focus groups discussions ( 2 in each district) in selected three districts with civil society representatives and key informants. The completed questionnaires were checked and entered into SPSS database designed for the survey. Before starting the analysis process, the dataset was weighted in order to reflect actual geographical and ethnic proportion. The data set was analyzed using the Statistical Package for Social Sciences (SPSS). For the data analysis, this study employed ten clusters of independent variables such as transparency, citizen participation, accountability, performance of functions, trustworthiness of public servants, political interference, public complaints, and right to information which are influencing citizens' trust in selected public institutions in the eastern province. On the other hand, citizens' trust was used as the dependent variable to measure the confidence in a number of public institutions in the eastern province of the country.

The area of this survey is the eastern province of Sri Lanka which consists of three main districts, namely Trincomalee, Batticaloa and Ampara. The province is positioned in the east coast of Sri Lanka and it is bounded in the east by the Bay of Bengal, North by the Northern Province, West by the North Central and Central Provinces and South by the Uva and Southern Provinces (Provincial Planning Secretariat, 2015). The province has three major ethnic communities of country namely Muslims, Tamils and Sinhalese inhibiting the three main districts of Trincomalee, Batticaloa and Ampara. The Muslims are a majority in Trincomalee which has a significant numbers of Sinhalese and Tamils. In Batticaloa, the Tamils and Muslims are majority. Ampara is Muslim dominant district having a substantial number of Sinhalese and Tamils (Provincial Planning Secretariat, 2015). The population of Eastern Province in terms of ethnicity is given below in the table 2.

Table 2. Population of eastern province based on ethnicity

\begin{tabular}{lcccccccc}
\hline Districts & $\begin{array}{l}\text { Land } \\
\left(\mathbf{~ k m}^{\mathbf{2}}\right)\end{array}$ & Tamils & Muslims & Sinhalese & Others & Male & Female & Total \\
\hline Ampara & 4,415 & 112,915 & 282,484 & 251,018 & 1640 & 314,810 & 333,247 & $\mathbf{6 4 8 , 0 5 7}$ \\
Batticalao & 2,854 & 424,199 & 154,197 & 3,303 & 4,902 & 285,447 & 301,154 & $\mathbf{5 8 6 , 6 0 1}$ \\
Trincomalee & 2,727 & 144,613 & 184,529 & 110,679 & 1,051 & 214,149 & 226,723 & $\mathbf{4 4 0 , 8 7 2}$ \\
Total & $\mathbf{9 , 9 9 6}$ & $\mathbf{6 8 1 , 7 2 7}$ & $\mathbf{6 2 1 , 2 1 0}$ & $\mathbf{3 6 5 , 0 0 0}$ & $\mathbf{7 5 9 3}$ & $\mathbf{8 1 4 , 4 0 6}$ & $\mathbf{8 6 1 , 1 2 4}$ & $\mathbf{1 , 6 7 5 , 5 3 0}$ \\
\hline
\end{tabular}

(Source: District Secretariats: Ampara, 2012; Batticaloa, 2012; Trincomalee, 2012)

This study is based on public institution that plays major role in building up not only nation's development but also needs of the people. It is notable that they are providing wide-ranging services to the people through various institutional mechanisms such as schools, hospitals, local government agencies, police stations and educational departments which have the authority from the law. In the case of eastern province, several public institutions are functioning under three tiers of different levels of governments (Central, Provincial and Local governments). The following table 3 illustrated the selected public institutions which are situated in the Eastern Province.

Table 3. Number of selected public institutions in eastern province

\begin{tabular}{clccc}
\hline S.No & \multicolumn{1}{c}{ Institutions } & Ampara & Batticaloa & Trincomalee \\
\hline 01 & Agricultural Service Centers & 32 & 20 & 24 \\
02 & Public Banks & 03 & 03 & 02 \\
03 & District Secretariats & 01 & 01 & 01 \\
04 & Divisional Secretariats & 20 & 14 & 11 \\
05 & Education Departments & 07 & 03 & 05 \\
06 & Grama Niladari & 503 & 345 & 230 \\
07 & Public Hospitals & 51 & 23 & 23 \\
08 & Local Governments & 20 & 12 & 13 \\
09 & Police & 16 & 15 & 12 \\
10 & Public Schools & 428 & 353 & 301 \\
\hline
\end{tabular}

(Source: District Secretariats: Ampara, 2012; Batticaloa, 2014; Trincomalee, 2011) 
The analytical framework was developed based on the correlations between the independent and dependent variables, and existing literature on citizens' trust in public institutions. The framework presents the method to analyze the parameters of citizens' trust. Independent variables like transparency, citizen participation, accountability, performance of functions, trustworthiness of public servants, political interference, public complaints and right to information are employed to assess the level of citizens' trust in public institutions. These independent variables are employed in the present study, given the significance of such independent variables which can underline the dynamic level of citizens' trust exists in the public institutions in the Eastern Province such as agricultural service centres, banks, district secretariats, divisional secretariats, education departments, grama niladari offices, hospitals, local governments, police and public schools.

\section{Results and Discussions}

This section outlines the results and discussions of the survey and it analyses various factors that influence the citizens' trust in public institutions in the eastern province of Sri Lanka. On the basis of these factors, this section shows the level of trust exists in public institutions.

\subsection{Transparency}

Public institutions should be transparent in its functions and activities, the empirical data from the eastern province shows that citizens point to various shortcomings in transparent governance. The local citizens predominantly stated a lack of transparency with regard to the financial management and service delivery of public institutions. Regarding the transparency of public institutions, one issue mentioned by the respondents of this study was corruption. The household survey also revealed that the majority of respondents were not aware of the activities of the public institutions in the eastern province. The findings retrieved from three districts show that people criticize the same issues with regard to the transparency of public institutions.

The respondents were asked to indicate their opinion in relation to the various activities of public institutions. According to the survey, most of the people $(66.60 \%)$ generally agree on the subject that public institutions deliver public services in the best possible way. Although, the particular amount of the respondents $(52.60 \%)$ generally agrees that public institutions pursue long-term objectives, only $40.60 \%$ of the respondents generally agree that people working in public institutions behave according to ethical standards aimed at avoiding corruption.

However, $25.20 \%$ of people have criticisms of the ethical standards followed by public institutions aimed at avoiding corruption. Approximately $40.40 \%$ of citizens generally agree that the public institutions treat all citizens fairly regardless of their gender, race, age or economic condition. But, nearly $43 \%$ of the respondents did not have the favorable response on the statement that public institutions are transparent with regard to their daily works. The respondents were also asked that do they have any witness of corruption taking place in the public institutions during the last three years. Most of the people in both Ampara (23.20\%) and Trincomalee (19.60\%) districts said that they have seen corruption taking place in the public institutions in their respective districts. But, $16.60 \%$ of respondents in Batticaloa district did not have the positive response regarding the witness of corruption.

The survey data shows that various forms of corruption (patronage, nepotism, embezzlement, misconduct in procurement, blackmailing, exchange of personal favors) are taking place in public institutions. However, majority people said that patronage (23.80\%), nepotism (19.00\%) and embezzlement $(21.20 \%)$ are the most common forms of corruption in public institutions in the eastern province of Sri Lanka. Further, people were asked how frequently corruption takes place in the selected public institutions in their province. According to their responses, corruptions are more frequently taking place in the police $(7.80 \%)$ and local governments $(7.20 \%)$. The larger portion of respondents pointed that corruptions are sometimes happening in their public institutions.

The interviewee and participants of focus groups also said that there is a lack of transparency in governing process of their public institutions owing to various reasons such as corruption, ethnic politics, party politics, influence of local political elites, contract procedures, past experiences and lack of proper supervision.

\subsection{Citizens' Participation}

This study used the citizens' participation as a key indicator to assess the level of citizens' trust in selected public institutions. One of the key findings in three district is that citizens' participation in the decision-making of public institutions is very less and the majority of people feel that they have less influence over public decision-making process of the particular institutions. The qualitative interviews also put forward positive responses on the above fact. 
On the topic of citizens' participation, respondents were asked to what extent they agree with some of the pre-structured statements as follows. $46.80 \%$ of respondents generally agreed that an ordinary citizen does not have sufficient expertise to decide whether a government decision was good or bad and $22.80 \%$ of the respondents fully agreed on the above statement. This indication suggests that the people have the lack of awareness with regard to their active participation in governing process of public institutions.

The people representatives should take over the responsibility of the citizens to shape public affairs because of ensuring the citizen based governance in public and political institutions. In this case, a large number of citizens $(47.80 \%)$ generally agree the above opinion. But, $19.40 \%$ of the respondents did not agree at all. The focus groups discussion also revealed the fact that the people representatives did not take over the responsibility of the citizens even though the citizens give the mandate to their representative.

Interestingly, a huge amount of the respondents did not have the favorable response with regard to the lobbying with politicians and decision makers. $41.20 \%$ of the respondents consider that lobbying with politicians and decision makers is bad for the society. Simultaneously, $73.60 \%$ of the respondents agreed that local public hearings are formal events and they have limited influence on local decisions. Meanwhile, $66.20 \%$ of respondents said that blogs and comments on the internet do not represent the public opinion properly.

Further, the respondents were asked whether they have ever attended a demonstration or rally or ever signed a petition. For this question, the responses were fully negative, since a large number of the respondents $(70.20 \%)$ of our household survey said that they never participated in a demonstration or rally or signed a petition. However, $17.20 \%$ of the respondents have the positive response on the participation of demonstration or rally and they have the experience of signing in a petition.

The active civil society participation is essential to enhance the level of citizens' participation and build the public confidence in public institutions. But, the key informants mentioned that public officers feel superior to the people and they did not ask for opinions of people, which is exactly the reason for the above lack of trust in terms of citizens' participation in public institutions. In this respect, a representative of civil society from Ampara said that: "The civil servants feel superior and they don't want to maintain a close relationship with the public. They did not listen to the public complaints and they follow their traditional rules and regulations. Unfortunately, there is a growing tendency among civil servants that their job or position is only for their own financial benefits."

\subsection{Accountability}

Accountability simply means public institutions are accountable to citizens. It has three important dimensions: financial, political and administrative accountability. In this respect, civil servants have a clear idea as to what and to whom they are accountable and it is also intensive. That is the performance goals should be clearly defined and measurable.

The people living in three districts felt that public institutions did not make their responsibility in a proper way and they are not accountable with regard to their responsibilities. In qualitative interviews, some important reasons such as the influence of political parties, lack of people awareness, less access to power and resources, top-down pressures, lack of people awareness, and gap between citizens and civil servants were put forward for the above precarious situations. Among those respondents who were more skeptical about the influence of civil society in the decision-making of public institutions, a strong argument was that civil servants would not listen to complaints and arguments from the public.

When citizens from the area have been asked in the household survey about what extent the selected public institutions can hold the government servant into account, the result was quite positive. $58.00 \%$ of the people think that Grama Niladharis are more accountable on their responsibility at the grass-root level. The survey further reveals that public banks $(55.80 \%)$ are also more accountable to their clients. It is observable that more than half of the total respondents agreed to the influential role of all selected public institutions. However, it is clear that $18.40 \%$ of people have dissatisfaction of accountability of local governments. On the subject of accountability, one of the participants in the focus group discussion said that:

"In fact, the public institutions are functioning based on the public money and they are established to perform public duties. Hence, civil servants should be accountable in terms of their responsibilities and be spending public money. In practice, the civil servants did not take any responsibility for their duty and never accountable to the public or taxpayers. The civil servants always forget their responsibilities and legitimacies of the civil service." 


\subsection{Performance of Functions}

The better performance of any institution usually increases the level of trust of clients in those institutions. In the case of public institutions in the eastern province, performance of the public institution is a problem which is determined, mainly, by the existence of some major shortages that make it hard to implement some public programs which are based on some performance objectives. In this respect, the respondents were asked to point out their opinion on the performance of the core functions of the selected institutions and the results of survey with regard to the performance of functions shows that the level of performance of functions of selected public institutions. According to the survey, a huge amount of respondents said that the level of performance of the particular institutions is in neutral level. However, the performance of public hospitals $(33.60 \%)$, education departments $(33.40 \%)$ and public schools $(31.00 \%)$ is in the good standard.

Further, the respondents were asked if they believe public institutions in their area can perform better. Most of the respondents $(45.40 \%)$ have positive answer. However, $36.00 \%$ of people responded that they believe the public institutions in their province could not perform well. The participants of informal interviews and focus group discussions indicated following reasons for the poor level of performance of selected public institutions; lack of will among public servants, lack of capacities, poorly qualified staff, interference of politics, non-transparent, promotion policies and practices, lack of vision and consistency. In this respect, a large number of people generally agree the above reasons behind the inefficient performance of selected public institutions in the eastern province.

The respondents were asked how satisfied they were with the current quality and professionalism of public services. On this subject, most of the citizens believe that the current quality and professionalism of public services is in the neutral level. However, more than $50 \%$ of citizens are satisfied with the quality and professionalism of the selected public institutions in their areas. A very few people are dissatisfied with the quality and professionalism of public services. Among them, most of the respondents raise the question about the quality and professionalism of local government, police and grama niladhari.

The qualitative interviews further confirm that the selected public institutions are more vulnerable in terms of their service quality and professionalism. The participants in the focus group discussions also mentioned that their public institutions bear witness for the institutional failure in the province. The participants in the focus group discussions from Ampara district, stated that the corruption, nepotism, unqualified staff, political interference, lack of relationships between public and civil servants, and the shortage of physical and human resources are the main reasons for the weakness of those public institutions with regard to their quality and professional nature.

When we interviewed the people, one of the interviewee said that: "As far as I am concerned, some of public institutions are functioning well in our province. Unfortunately, the most of the public institutions far-away from people and they did not follow their mandate to ensure the better public governance. Although, most of the public institutions have a large number public personals, majority of them are not suitable to the public sector in terms of their attitudes and qualifications. It is notable here that our public institutions keep close relations with regional or rural elites. Sometimes, they have a good rapport with political elites."

\subsection{Trustworthiness of Public Servants}

Several aspects determine trustworthiness of public servants. According to the pre-structured questionnaire, the following aspects: prompt and efficient, corrupt, serve their personal interests, helpful and responsive, friendly, disrespectful to citizens, difficult to access, reliable / trustworthy, treat all equality, not fully aware of their responsibilities and follow nepotism are used to assess the level of trustworthiness of public servants.

According to the survey, $58.00 \%$ of respondents partly agree that their public servants are prompt and efficient. Meanwhile, a particular amount of citizens $(16.20 \%)$ strongly stated that they are disrespected by public servants. Corruption of public servants was mentioned as a key issue by $10.40 \%$ of people. According to the survey results, nepotism is also a significant problem. Hence, $15.80 \%$ of the respondents strongly believe that civil servants practice nepotism. Nevertheless, a precise extent of respondents accept that civil servants are reliable, helpful and responsive to the citizens. With regard to the professions of civil servants, people were asked the image of public servants whether it is positive or negative. $52.80 \%$ of the respondents positively answered about the image of civil servants.

The treatment of public servants also determines the level of trustworthiness of civil servants. According to the survey results, most of the people (42.80 \%) stated that public servants sometimes fairly treat people. But, $36.60 \%$ of people said that fair treatment of civil servants is very seldom. When asked about the treatment of public 
servants upon people based on their social status, a huge number of people (53.40\%) agree that the civil servants treat the people according their social status, while $12.60 \%$ of the respondents totally denied the above argument.

In respects of corruption of public servants, most of people from Ampara (11.80\%) and Trincomalee (13.00\%) said that some public servants are involved in corruption. In the case of Batticaloa district, most of the people $(13.00 \%)$ don't have any opinion about the corruption dealing of public servants. Interestingly, $0.60 \%$ of the respondents from Ampara district alleged that everybody is involved in corruption. In the qualitative interview, people also stated that some of public servants are involved in the corruption due to their low income. According to the survey results, $34.40 \%$ of the respondents stated that public servants sometimes are involved in corruption dealing. On the other hand, $2.80 \%$ of households responded that all the public servants have involved in corruption.

\subsection{Political Interference}

In Sri Lankan context, public institutions are legally ruled by central or provincial governments. The public institutions depend on politicians and parties in power for resource allocations and other physical and human supports. As the reason, intervention of politics is viewed as an unavoidable aspect in public sector governance.

In this respect, citizens were asked to what extent politics intervenes in the agenda of the selected institutions. Their responses were quite interesting. A huge number of people agreed that political interference exist in all selected institutions. However, local government $(26.80 \%)$ and police $(17.60 \%)$ have had very much political interference. There are several aspects interrelated with the intervention of politics in the public institutions. Such types of aspects are structured as statements in the particular survey. In this respect, most of the respondents $(32.60 \%)$ agreed that the women and men have same access to the public services while $29.20 \%$ of people is in the neutral position on the same aspect.

However, $15.60 \%$ of people disagree the fact that public servants serve with the same devotion and ethics to women and men. On gender equalities and exclusion of women, $24 \%$ of respondents believe that public institutions are doing their best in combating gender inequalities and exclusion of women. But $14.60 \%$ people refute the above argument. As it was mentioned earlier, transparency and accountability in the work of public institutions is another important issue in terms of the functions of public institutions. According to the survey, $22.40 \%$ people disagree that there is transparency and accountability in the work of public institutions although $26.80 \%$ of the respondents agreed the statement.

With regard to the statement that public institutions are opened to consult with civil society and interest groups in decision making and implementation, $26.20 \%$ people responded positively and $16.20 \%$ denied the fact. According to the questionnaire results, it is clear that suggestions and inputs by civil society and other interest groups are considered and reflected by public institutions in a particular extent.

\subsection{Public Complaints}

The system for public complaints is an important factor to ensure the good governance in public institutions. With regard to this aspect, the respondents were asked whether they were aware of public institutions having a system to receive complaints from citizens with regard to their dissatisfaction with public service delivery. The answer for the above question was quite different. $37.60 \%$ of the respondents stated that they are aware about such system and $38.20 \%$ of the respondents said that they don't know about the system of complaints with regard to their dissatisfaction with service delivery.

In regard to question to the public institutions listening to and properly addressing the complaints coming from citizens, $30.00 \%$ of the respondents from said that the public institutions do not listen to the complaints coming from citizens, while $33.40 \%$ of the respondents said that they don't have any idea about addressing public complaints. In terms of public complaints, there are multiple or very different opinions exist among the citizens in the above three districts.

\subsection{Right to Information}

The right to information is an essential democratic value that promotes effectiveness and efficiency of public institutions. It also increases the level of performance of civil servants and citizens' trust in public institutions. In our survey, the respondents were asked whether they have ever filed a formal request for public information or data. According to the results of responses, most of them (72.40\%) said that they filed a formal request for public information or data. However, $27.60 \%$ of respondents denied the fact. The survey results describe that most of the people believe that open data improve quality of citizens' life, promote economic development, increases the trust of citizens towards the government, and strengthens the relationships between government and citizens. 
However, qualitative interviews revealed that getting and accessing the public data are a problematic issue in the Sri Lankan context. Some people from focus group discussion said that although the government has recently passed legislation on rights to information, citizens did not obtain full benefits of such legislation. It was also revealed that some public officials also deny the request of the public information.

\subsection{Level of Citizens' Trust}

There are several public institutions in the eastern province that people have direct or indirect dealings with these institutions. The respondents were asked how much trust they have in the selected public institutions. With regard to the level of trust that they have, most of respondents from all three districts have medium level trust in all selected public institutions.

Most people from Batticaloa and Ampara have a great deal of trust in the Banks and public schools. However, a particular amount of people stated that they have low level trust in the both institutions. On the agricultural service centers, most of the respondents said that they do not know as to how much trust they have. It is clear that trust in certain institutions in Batticaloa district is comparatively higher than the similar institutions in other two districts. The below figure 1 summarizes the degree of citizens' trust in selected organizations for this survey; Agricultural Service Centers, Banks, District Secretariats, Divisional Secretariats, Education Departments, Grama Niladari, Hospitals, Local Governments, Police and Public Schools.

With regard to the service delivery of public institutions, the respondents were asked how satisfied they are with the service delivery of selected public institutions. The results of responses are given in the following figure. According to the figure 2, most of the people are satisfied with the service delivery of the particular institutions. A few numbers of respondents are dissatisfied with the service delivery of public institutions. Among them, local government $(24.40 \%)$ and police $(20.80 \%)$ have scored highest percentage of dissatisfaction. When it was asked directly what they think influenced their levels of trust in public institutions, people offer a wide range of obvious factors such as lack of awareness among people, discrimination in terms of ethnicity, unwanted delay, lack of modern facilities and political influence. 


\section{Level of Trust in Public Insitutions}

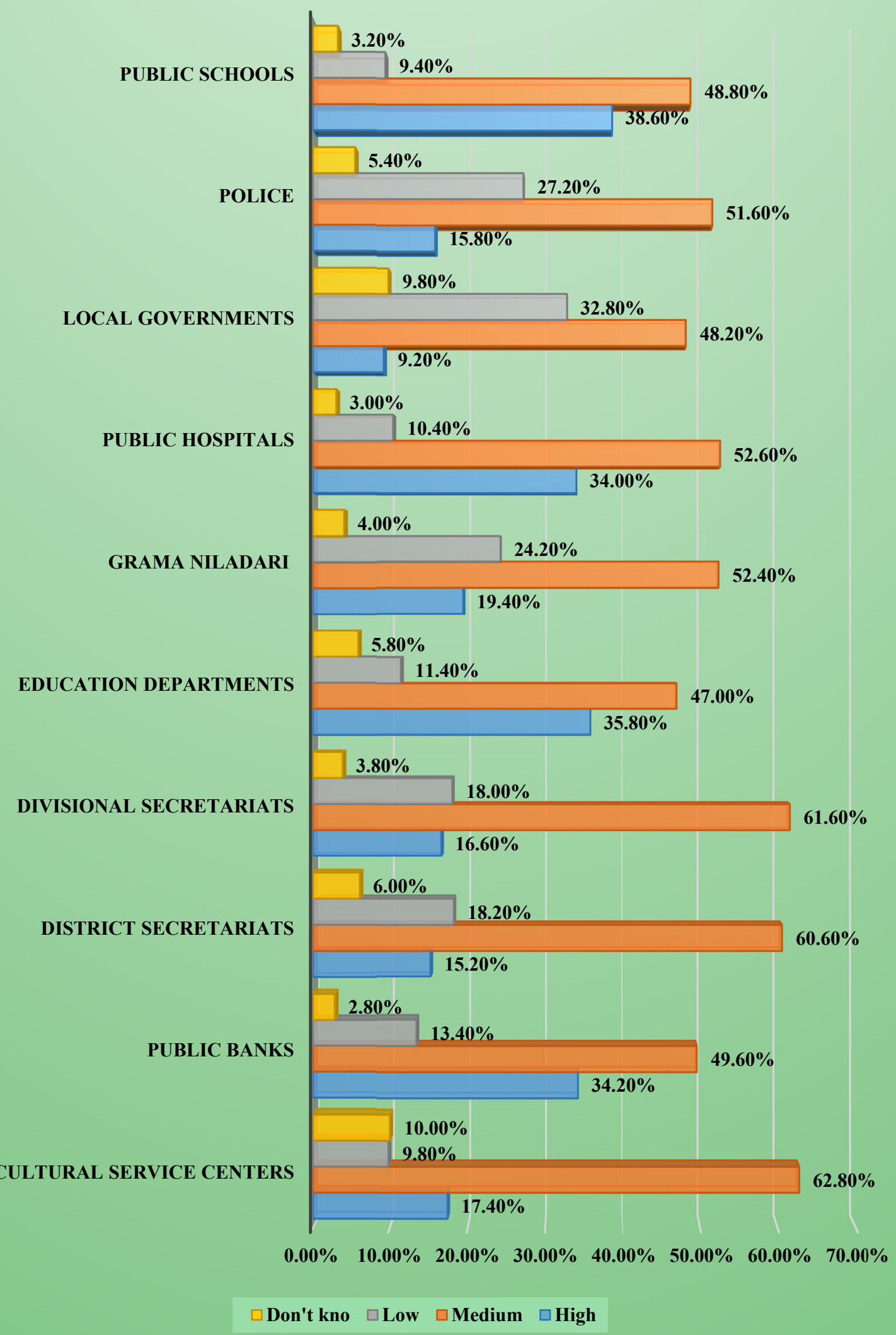

Figure 1. Level of trust in public institutions (provincial level) 


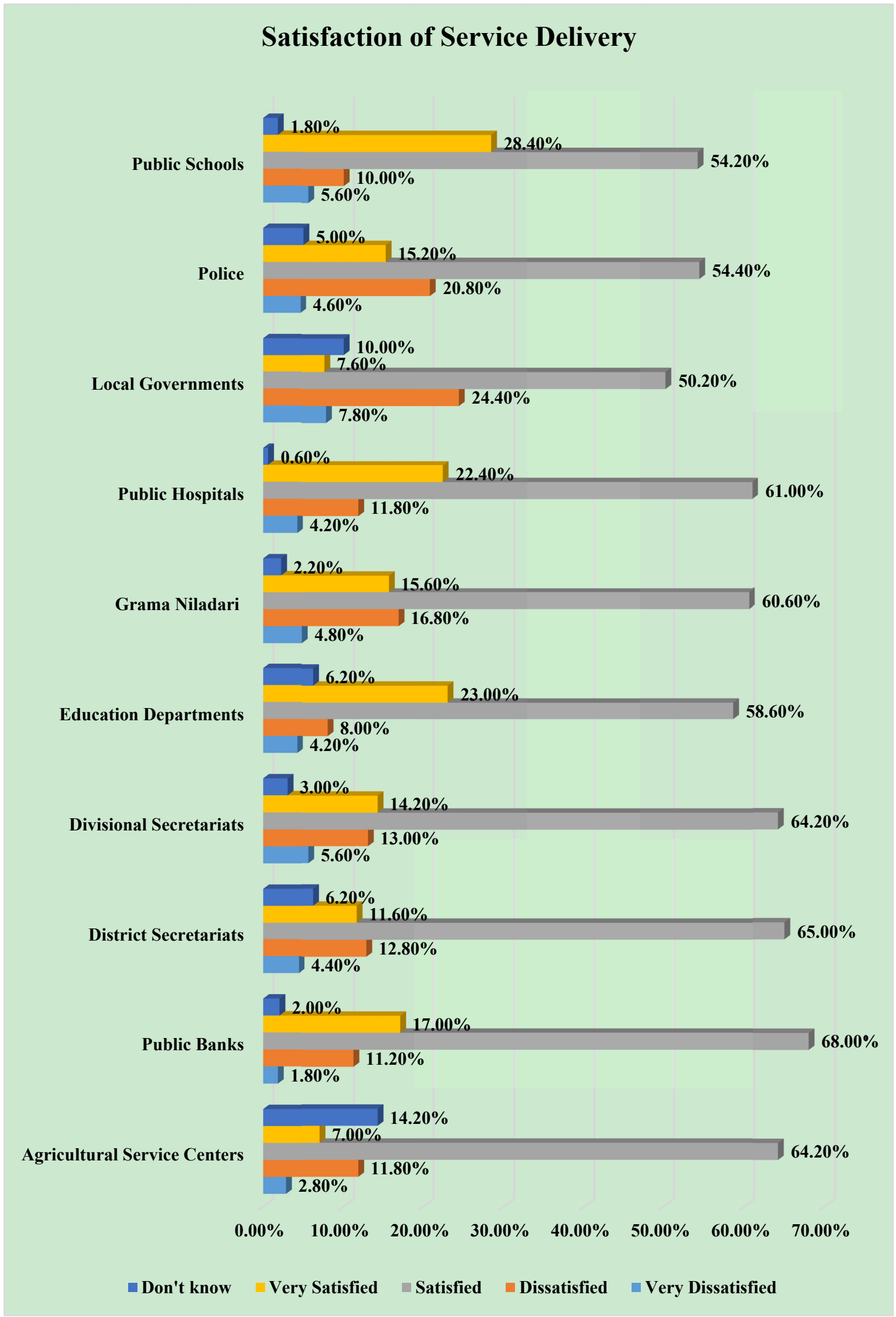

Figure 2. Satisfaction of service delivery 


\section{Conclusion}

The findings of study reveals that citizens have given priority to the transparent governance of public institutions. In terms of transparency, corruption was highlighted as a key issue submerging the public institutions in the researched area and of which, patronage, nepotism, embezzlement, misconduct in procurement, blackmailing, exchange of personal favors were prominent in the form of corruption.

The study also found that the citizens' participation in the decision making process of public institutions is very less and majority of people believe that they have little role on public institutions. Most importantly, it was found that accountability is a major issue in public institutions. However, people have balanced opinions towards the public institutions as far as their functions are concerned. Lack of will among public servants, lack of capacities, poorly qualified staff, interference of politicians, non-transparent, and lack of vision and consistency are the main factors influencing the level of performance and professionalism in the public institutions.

The study also found that the level of citizens' trust is in an average level in all selected public institutions. Interestingly, it was found citizens' trust in certain institutions in Batticaloa district is comparatively higher than that of other two districts. Lack of qualified staff, unwanted controls from the central government, lack of finance, lack of awareness, unnecessary political interference, complex nature of social structure, attitude of both civil servants and citizens, immature administrative culture, lack of civil society activism, urbanization, and lack of private partnership are identified as the contributing factors to the decline of citizens' trust in public institutions.

Overall, it was found that the people have little trust in the public institutions due to the lack of awareness, discrimination in terms of ethnicity, unwanted delay, lack of modern facilities and political influence. Political interference, corruption, lack of accountability, etc. are repeatedly highlighted by the respondents as the significant factors contributing to the decline of citizens' trust in public institutions in the researched area. Therefore, it is of paramount importance upon those policy makers and rulers to take these factors seriously and address them immediately to restore citizens' trust on these institutions. To effectively address the above issues, this survey suggests the following recommendations:

- Addressing issues of service delivery and improving communication and information flow

- Adopting people oriented or bottom-up approach to deliver public services to meet the expectations of citizens.

- Adopting technological innovations (e-government) to make public institutions more efficient, inclusive and accessible to the citizens.

- Ensuring active and extensive citizens engagement in the policy making and policy implementation process of public institutions.

- Implementing citizen charter effectively and establishing a monitoring mechanism to listen citizens' compliances.

- Increasing the capacity of public institutions to design and implement programs to protect the rights of citizens.

- Increasing administrative openness by expanding the disclosure of administrative information and enhancing access to it.

- Introducing social reforms that will strengthen civil society participation in public affairs and producing wide range of opportunities for the convenient and efficient participation of public in government affairs.

- Preventing abuse of authority in public institutions by establishing self-regulating constraint mechanisms.

- Preventing various forms of corruption such as patronage, nepotism, embezzlement, misconduct in procurement, blackmailing, exchange of personal favors.

- Reducing service costs and financial excesses through establishing a better financial management system.

- Replacing unwieldy administrative procedures with more simplified and transparent and reducing red tape.

- Restructuring the mandates and functions of institutions and reforming national and provincial administration. 
- Stimulating the openness of public institutions and the engagement of citizens through the expansion of the participation of citizens in public institutions.

- Strengthening public responsibility, enhancing the capacity of public institutions, ensuring the inclusion of different social groups into administrative structure.

- Strengthening the responsibility of public institutions, and increasing the transparency and soundness of public financial management.

It is also noted here that this survey was conducted with limited scope, time and resources. The survey tried to assess only the level of citizens' trust in public institutions of a particular province with a few selected indicators. In this line, it can be extended furthermore with defining new variables or indicators to get more sound findings in different aspects. Hence, there is a need for further empirical survey.

As we mentioned in the beginning part of this survey, this study builds upon existing knowledge and continues a trend toward the deconstruction of citizen's trust in public institutions, and thus enhance a better understanding of the dynamics of citizens' trust in public institutions.

Eventually, this survey provides a comprehensive, independent, and critical discussion about the actions required of various sectors of society and institution to strengthen citizen's trust in public institutions and the findings of this survey can also be used by public servants and policy makers to improve the level of citizens' satisfaction and trust.

\section{References}

District Secretariat. (2011). Statistical Handbook - 2012. Trincomalee, Sri Lanka: District Secretariat.

District Secretariat. (2012a). Statistical Handbook - 2012. Trincomalee, Sri Lanka: District Secretariat.

District Secretariat. (2012b). Statistical Handbook - 2012. Ampara, Sri Lanka: District Secretariat.

District Secretariat. (2012c). Statistical Handbook - 2012. Batticaloa, Sri Lanka: District Secretariat.

District Secretariat. (2014). Statistical Handbook - 2012. Batticaloa, Sri Lanka: District Secretariat.

Fernando, N. (1973) Regional Administration in Sri Lanka. California: Academy of Administrative Studies, University of California.

Fernando, N. (Ed.). (1980). Public Management. Colombo: Sri Lanka Institute of Development Administration.

Jamil, I., Askvik, S., \& Dhakal, T. N. (2013). In Search of Better Governance in South Asia and Beyond. New York: Springer. https://doi.org/10.1007/978-1-4614-7372-5

Marozzi, M. (2014). Construction, Dimension Reduction and Uncertainty Analysis of an Index of Trust in Public Institutions. International Journal of Methodology, 48(2), 939-953. https://doi.org/10.1007/s11135-012-9815-z

Mendis, D. (Ed.). (2008). Electoral Process and Governance in South Asia. Los Angeles: SAGE Publications.

Nanayakara, G. (1994). Public Accountability and the Role of the Citizen in Government. Colombo: Postgraduate Institute of Management, Sri Jayewardenepura University.

Provincial Planning Secretariat. (2015). Eastern Development Plan. Eastern Province, Sri Lanka: Provincial Planning Secretariat.

Ramesh, R., \& Umadevi, D. (n.d). Citizens' Trust in Public Institutions: The Case of Sri Lanka. Retrieved from https://www.academia.edu/27531819/Citizens_Trust_in_Public_Institutions_The_Case_of_Sri_Lanka

Ranatunga, D. C. (2002). The Twelve Parliaments of Sri Lanka. Colombo: Sarasavi Publishers.

Rothstein, B., \& Torell, J. (2008). What is Quality of Government? A Theory of Impartial Government Institutions. International Journal of Policy, Administration, and Institutions, 21(02), 165-190. https://doi.org/10.1111/j.1468-0491.2008.00391.x

Silva, K. M. De. (Ed.). (1993). Sri Lanka: Problems of Governance. Kandy: International Centre for Ethnic Studies.

Somasundram, M. (Ed). (1997). The Third Wave: Governance and Public Administration in Sri Lanka. Colombo: Konark Publishers Pvt. Ltd.

Sztompka, P. (1999) Trust: A Sociological Theory. Cambridge: Cambridge University Press.

Warnapala, W. (1974). Civil Service Administration in Ceylon: A Study in Bureacratic Adaptation. Colombo: 
Post graduate Institute of Management, Sri Jayewardenepura University.

Wijeweera, B. S. (1988). A Colonial Administrative System in Transition: The Experience of Sri Lanka. Colombo: Marga Publication.

\section{Copyrights}

Copyright for this article is retained by the author(s), with first publication rights granted to the journal.

This is an open-access article distributed under the terms and conditions of the Creative Commons Attribution license (http://creativecommons.org/licenses/by/4.0/). 